\title{
POLITIK HUKUM PERTAMBANGAN MINYAK BUMI PADA SUMUR TUA SEBAGAI STRATEGI MENUJU KETAHANAN ENERGI DI INDONESIA
}

\author{
(Politics of Law in Oil Mining on Old Well as a Strategy to Energy Security in Indonesia)
}

\author{
Ananda Prima Yurista \\ Pusat Kajian Dampak Regulasi dan Otonomi Daerah (SadarOtda) \\ Fakultas Hukum Universitas Gadjah Mada \\ Blok E-12, Bulaksumur, Sleman, D.I. Yogyakarta \\ Email: aprimayurista@gmail.com \\ Dian Agung Wicaksono \\ Bagian Hukum Tata Negara Fakultas Hukum Universitas Gadjah Mada \\ Jl. Sosio Yustisia No. 1 Bulaksumur, Sleman, D.I. Yogyakarta \\ Email: dianagung@ugm.ac.id
}

Naskah diterima: 27 Juni 2015; revisi: 13 Agustus 2015; disetujui: 19 Agustus 2015

\begin{abstract}
Abstrak
Pengelolaan pertambangan minyak bumi pada sumur tua terbagi dalam tiga aspek, yaitu perencanaan, pelaksanaan, dan pengawasan. Pengelolaan pertambangan minyak bumi pada sumur tua juga memiliki hambatan permasalahan, yaitu norma pengaturan dan praksis pengusahaan. Norma pengaturan tidak serta merta membuka pintu keterlibatan daerah melalui BUMD untuk dapat berpartisipasi dalam pengusahaan minyak bumi pada sumur tua. Aspek praksis pengusahaan juga dibenturkan pada aspek ketersediaan modal, data sumur tua, hambatan teknis di lapangan, lahan lokasi sumur tua, dan pengawasan. Penelitian ini merupakan penelitian yuridis normatif. Adanya peluang yang diberikan kepada BUMD atau KUD untuk ikut mengusahakan sumur tua menjadi sebuah harapan baru untuk dapat mengoptimalisasi produksi minyak bumi pada sumur tua sebagai salah satu strategi menuju ketahanan energi di Indonesia. Diperlukan pembenahan yang holistik, baik dari aspek norma pengaturan, maupun dari aspek praksis pelaksanaan pengusahaan minyak bumi pada sumur tua. Selain itu, pemerintah harus melaksanakan implementasi norma dalam Pasal 16 dan Pasal 17 Undang-Undang Nomor 22 Tahun 2001 mengenai pengembalian wilayah kerja, sebagai sebuah upaya agar pengelolaan minyak bumi pada sumur tua dapat dilakukan BUMD dan KUD secara mandiri.
\end{abstract}

Kata Kunci: politik hukum, pertambangan minyak bumi, sumur tua

\begin{abstract}
Management of oil mining in old wells are divided into three aspects, namely planning, implementation, and supervision. Management of oil mining in old wells also have a bottleneck problem, namely regulations and practices. Regulations do not necessarily open the door for local government enterprises (BUMD) to participate in the exploitation of oil in old wells. Practical aspects of exploitation are also collided with the aspect of availability of capital, old wells data, technical barriers in the field, old well locations, and supervision. This research is a normative juridical research. The opportunities given to BUMD or village unit cooperatives (KUD) to participate in exploitation of old wells become a new hope to optimize oil production in old wells as a strategy towards energy security in Indonesia. Holistic improvements are needed, both from the aspect of regulation, as well as the practical aspects of the implementation of the exploitation of oil in old wells. In addition, the government should implement norms set out in the Article 16 and Article 17 of Law Number 22 Year 2001 regarding the return of the working area, as an effort for the management of oil mining in old wells can be operated independently by BUMD and KUD.
\end{abstract}

Keywords: politic of law; oil mining; old well 


\section{A. Pendahuluan ${ }^{1}$}

Indonesia merupakan negara yang dianugerahi cakupan kewilayahan yang luas dengan kandungan kekayaan alam yang sangat berlimpah, sehingga tidak berlebihan bila sejak awal berdirinya Negara Kesatuan Republik Indonesia, para founding father mengamanatkan untuk mempergunakan bumi dan air dan kekayaan alam yang terkandung di dalam alam Indonesia dikuasai oleh Negara dan untuk sebesar-besarnya kemakmuran rakyat. ${ }^{2}$ Salah satu kekayaan alam yang ada di Indonesia adalah kandungan minyak bumi. Minyak bumi merupakan sumber daya alam strategis tidak terbarukan yang dikuasai oleh negara serta merupakan komoditas vital yang menguasai hajat hidup orang banyak dan mempunyai peranan penting dalam perekonomian nasional sehingga pengelolaannya harus dapat secara maksimal memberikan kemakmuran dan kesejahteraan rakyat. $^{3}$ Oleh karena itu, eksploitasi minyak bumi dilaksanakan secara besar-besaran untuk memberikan pemasukan bagi negara, dengan tujuan untuk memberikan kemakmuran sebesar-besarnya bagi kesejahteraan seluruh rakyat. Namun di sisi lain, penambangan besar-besaran pada obyek yang tak terbarukan tersebut menyebabkan ketersediaan sumber daya minyak dan gas di Indonesia semakin berkurang.
Di tengah tuntutan untuk peningkatan produksi minyak bumi, keberadaan sumur tua minyak bumi dapat menjadi alternatif solusi yang patut untuk dipertimbangkan, mengingat banyak sumur tua yang ditinggalkan dan tidak berproduksi kembali. Sumur tua adalah sumursumur minyak bumi yang dibor sebelum tahun 1970 dan pernah diproduksikan serta terletak pada lapangan yang tidak diusahakan pada suatu wilayah kerja yang terikat kontrak kerja sama dan tidak diusahakan lagi oleh kontraktor. ${ }^{4}$ Bukan hanya membantu peningkatan produksi minyak bumi, pertambangan minyak bumi pada sumur tua juga memberikan peluang untuk meningkatkan kesejahteraan masyarakat sekitar sumur tua untuk turut serta melakukan proses penambangan dan produksi minyak bumi pada sumur tua.

Ketersediaan minyak bumi menjadi hal yang penting untuk terus diupayakan keberlanjutannya. Terlebih saat ini, cadangan minyak bumi di Indonesia semakin menurun, namun kebutuhan akan minyak bumi justru terus meningkat. Produksi total minyak Indonesia turun dari 1,245 juta barel per hari di tahun 2003 menjadi 1,183 juta barel per hari di tahun 2004, sementara itu konsumsi dalam negeri meningkat dari 1,143 juta barel per hari di tahun yang sama menjadi 1,233 juta barel per hari pada tahun 2004. ${ }^{5}$ Jumlah produksi minyak bumi Indonesia yang mencapai puncak pada tahun 1995 yakni 
sejumlah 1,6 juta, pada tahun 2013 menurun menjadi 826.000 barel. ${ }^{6} \mathrm{Hal}$ tersebut ditegaskan oleh Kementerian Energi dan Sumber Daya Mineral yang menyatakan, Indonesia saat ini defisit minyak bumi 608.000 barrel per hari. ${ }^{7}$ Adapun produksi minyak Indonesia yang dapat diolah di kilang dalam negeri hanya sekitar 649.000 bph. $^{8}$ Sementara kebutuhan BBM dalam negeri mencapai 1,25 juta bph. ${ }^{9}$ Dengan demikian, mau tidak mau Pemerintah harus melirik sumber energi alternatif dan berupaya mencari sumber cadangan minyak bumi lainnya untuk memenuhi kebutuhan akan minyak bumi yang sudah pasti bertambah.

Di tengah semakin meningkatnya kebutuhan akan minyak bumi, produksi minyak bumi di Indonesia justru menurun. Pada 2014, Indonesia memproduksi kira-kira 794.000 barrel minyak per hari (bmph), jauh di bawah target pemerintah produksi minyak yang tertera di APBN 2014 (818.000 bmph). ${ }^{10}$ Padahal pada tahun 2013, produksi minyak bumi Indonesia mencapai 826.000 bmph, jauh dari puncak produksi Indonesia sebesar 1,6 juta bmph pada tahun 1995 pada masa rezim Orde Baru Suharto. ${ }^{11} \mathrm{Hal}$ ini menunjukkan bahwa produksi minyak bumi terus menerus turun sejak masa rezim Orde Baru hingga saat ini. Dalam rangka meningkatkan produksi minyak bumi, keberadaan sumur tua minyak bumi dapat menjadi alternatif solusi yang patut untuk dipertimbangkan.

Pengusahaan minyak bumi pada sumur tua ini memang diharapkan mampu meningkatkan produksi minyak bumi nasional. Pemerintah menawarkan 13 ribu sumur minyak bumi tua kepada KUD dan BUMD untuk diproduksi kembali, melalui kerja sama Kontrak Jasa dengan KKKS dan PT Pertamina. ${ }^{12}$ Langkah ini diharapkan bisa menambah produksi minyak nasional sekitar 5 ribu hingga 12 ribu barel per hari (bph). ${ }^{13}$ Berdasarkan hal tersebut maka pertambangan minyak bumi pada sumur tua merupakan sebuah alternatif riil yang sudah semestinya dioptimalkan untuk menambah cadangan minyak nasional serta meningkatkan ketahanan energi di Indonesia.

Dikaitkan dalam kerangka otonomi daerah, daerah melalui Badan Usaha Milik Daerah (BUMD) diperkenankan untuk mengusahakan dan memproduksikan minyak bumi setelah mendapat persetujuan Menteri ESDM. ${ }^{14}$ BUMD dapat mengajukan permohonan kepada kontraktor untuk melaksanakan pengusahaan

\footnotetext{
6 Siska Amelie F. Deil, "Kisah Indonesia yang Tercoret dari Daftar Negara Kaya Minyak," http://m.liputan6.com/ bisnis/read/786193/kisah-Indonesia-yang-tercoret-dari-daftar-negara-kaya-minyak?p=2 (diakses 5 Oktober 2015).

7 Erlangga Djumena, “Indonesia Defisit Minyak Bumi 608.000 Barrel Per hari,” (Kompas, 24 Maret 2014).

8 Ibid.

9 Ibid.

10 Indonesia Invesment, “Minyak \& Gas Indonesia: Produksi Minyak Mentah Meningkat di 2015?," http://www. Indonesia-investments.com/id/berita/kolom-berita/minyak-gas-Indonesia-produksi-minyak-mentahmeningkat-di-2015/item5385 (diakses 15 Juni 2015).

11 Ibid.

12 Kementerian Energi dan Sumber Daya Mineral, "13 Ribu Sumur Minyak Bumi Tua Ditawarkan Kepada KUD dan BUMD," http://esdm.go.id/berita/40-migas/1636-13-ribu-sumur-minyak-bumi-tua-ditawarkan-kepada-kuddan-bumd.html (diakses 15 Juni 2015).

13 Ibid.

14 Pasal 2 ayat (2) Peraturan Menteri Energi dan Sumber Daya Mineral Nomor 1 Tahun 2008 tentang Pedoman Pengusahaan Pertambangan Minyak Bumi pada Sumur Tua.
} 
dan pemroduksian minyak bumi pada sumur tua. Pengusahaan pertambangan minyak bumi ini bertujuan untuk mengoptimalkan produksi minyak bumi di suatu wilayah kerja dan meningkatkan kesejahteraan masyarakat di sekitar sumur tua.

Pun, BUMD diberikan kesempatan untuk turut serta mengusahakan sumur tua, namun kontrol dari pemerintah pusat relatif kental dalam pemberian izin pengusahaan sumur tua di daerah. Padahal urusan pertambangan bukanlah urusan yang menjadi domain dari pemerintah pusat. ${ }^{15}$ Otonomi daerah yang merupakan pelimpahan urusan dari pemerintah pusat kepada pemerintahan daerah seharusnya membuat daerah memiliki kewenangan penuh dalam mengelola sumber daya alam yang ada di daerah. Terlihat terdapat nuansa ego sektoral dalam pengaturan Peraturan Menteri ESDM Nomor 1 Tahun 2008 tentang Pengusahaan Pertambangan Minyak Bumi pada Sumur Tua.

Berdasarkan penjabaran di atas, maka patut ditelaah lebih lanjut dalam konteks politik hukum pengelolaan pertambangan minyak bumi pada sumur tua. Pengelolaan pertambangan minyak bumi pada sumur tua terkait erat dengan kesejahteraan masyarakat daerah dan partisipasi aktif daerah untuk terlibat langsung dalam pengelolaan sumber daya alam yang ada di daerah. Dalam lingkup pengelolaan, pertambangan minyak bumi pada sumur tua berfokus pada tiga hal, yaitu perencanaan, pelaksanaan, dan pengawasan. Pada ketiga hal tersebut memiliki peluang dan tantangan dalam rangka pengusahaan kembali pertambangan minyak bumi pada sumur tua.

\section{B. Metode Penelitian}

Penelitian ini merupakan penelitian yuridis normatif, yang artinya penelitian ini lebih menitikberatkan penelitian kepustakaan (library research) yang gunanya untuk memperoleh data sekunder penelitian. Data sekunder dalam penelitian ini didapatkan dengan studi dokumen, yang dilakukan dengan menelusuri berbagai peraturan perundang-undangan, buku, jurnal, makalah dan data kepustakaan lainnya yang berkaitan dengan permasalahan yang dibahas. Penelitian hukum normatif maka data yang terkait dengan penulisan hukum ini dianalisis secara deskriptif kualitatif, yaitu dengan melakukan analisis yang pada dasarnya dikembalikan pada tiga aspek, yaitu mengklasifikasi, membandingkan, dan menghubungkan. Terhadap data-data yang telah terkumpul dari penelitian kepustakaan selanjutnya akan dianalisis secara kualitatif untuk menjawab permasalahan penelitian yang diajukan.

\section{Pembahasan}

\section{Politik Hukum Pengelolaan Pertambangan Minyak Bumi pada Sumur Tua}

Bumi, air, serta kekayaan alam yang ada di Indonesia dikuasai oleh negara dan dipergunakan sebesar-besarnya untuk kemakmuran rakyat. ${ }^{16}$ Pengaturan tersebut merupakan landasan dari Hak Menguasai Negara (HMN), yang mana HMN merupakan sebuah instrumen (bersifat instrumental), sedangkan "dipergunakan 
untuk sebesar-besarnya kemakmuran rakyat" merupakan tujuan (objectives), ${ }^{17}$ sehingga hakikatnya $\mathrm{HMN}$ adalah instrumen untuk mencapai kebergunaan untuk sebesar-besarnya kemakmuran rakyat. Pencapaian tujuan ini, bersesuaian pula dengan salah satu tujuan negara, yaitu untuk memajukan kesejahteraan umum, sebagaimana termaktub dalam Pembukaan Undang-Undang Negara Republik Indonesia Tahun 1945 (UUD NRI Tahun 1945).

Bumi, air, dan kekayaan alam yang ada di dalamnya, termasuk berupa minyak bumi tersebut menjadi sumber daya alam potensial untuk dimanfaatkan demi sebesar-besarnya kemakmuran rakyat. Potensi minyak bumi di Indonesia tersebar di berbagai pelosok daerah. Namun realitanya, industri minyak bumi belum sepenuhnya mendukung pembangunan nasional, khususnya pembangunan di daerah. Fakta di lapangan memperlihatkan bahwa sentra-sentra minyak bumi di berbagai daerah merupakan kantong-kantong kemiskinan yang masih tergantung dengan kebijakan dan bantuan dari pemerintah. ${ }^{18}$ Padahal lazimnya, daerah yang menjadi lokasi penghasil minyak bumi tersebut menjadi prioritas untuk memperoleh kemanfaatan, khususnya dalam hal peningkatan kesejahteraan masyarakat daerah.

Berbicara mengenai upaya peningkatan kesejahteraan masyarakat daerah, maka tidak terpisah dengan lahirnya konsep otonomi daerah. Bahwa otonomi daerah dilaksanakan dalam rangka penyelenggaraan pemerintahan daerah sesuai dengan amanat UUD NRI Tahun 1945, yaitu mengatur dan mengurus sendiri urusan pemerintahan menurut asas otonomi dan tugas pembantuan, untuk mempercepat terwujudnya kesejahteraan masyarakat melalui peningkatan, pelayanan, pemberdayaan, dan peran serta masyarakat, serta peningkatan daya saing daerah dengan memperhatikan prinsip demokrasi, pemerataan, keadilan, keistimewaan dan kekhususan suatu daerah dalam sistem Negara Kesatuan Republik Indonesia. Hal tersebut menegaskan bahwa adanya otonomi daerah adalah untuk mempercepat kesejahteraan masyarakat di daerah, sehingga dalam hal peningkatan kesejahteraan maka masyarakat daerah patut diprioritaskan.

Hakikat dari otonomi daerah adalah kewenangan untuk mengelola urusanurusan yang dilimpahkan, termasuk dalam hal mengelola potensi daerah, khususnya menyangkut pengelolaan sumber daya alam. ${ }^{19}$ Pengelolaan sumber daya alam oleh daerah tersebut salah satu wujudnya diatur dalam pengaturan Pasal 9 Undang-Undang Nomor 22 Tahun 2001 tentang Minyak dan Gas Bumi (UU Migas), yang menyebutkan bahwa BUMD, koperasi atau usaha kecil diberikan kesempatan untuk melaksanakan Kegiatan Usaha Hulu dan Kegiatan Usaha Hilir. ${ }^{20}$ Peluang keikutsertaan

17 Bagir Manan, Beberapa Catatan Atas Rancangan Undang-Undang tentang Minyak dan Gas Bumi, (Bandung: Fakultas Hukum Universitas Padjadjaran, 1999), hlm. 1-2.

18 N.F. Sinaga, Participating Interest dalam Kegiatan Usaha Hulu Minyak dan Gas Bumi Ditinjau dari Otonomi Daerah (Keikutsertaan BUMD dalam Participating Interest Blok Cepu), (Jakarta: Fakultas Hukum Universitas Indonesia, 2009), hlm. 1.

19 S. Asikin, "Pengembangan Potensi Sumber Daya Mineral Menyongsong Otonomi Daerah," (Makalah Seminar dan MUNAS I Ikatan Alumni Tambang Jurusan Teknik Pertambangan UPN Veteran Yogyakarta, Yogyakarta, 23 Juni 2000), hlm. 3.

20 Pasal 9 Undang-Undang Nomor 22 Tahun 2001 tentang Minyak dan Gas Bumi (Lembaran Negara Republik Indonesia Tahun 2001 Nomor 136). 
daerah pun juga dipertegas dalam Pasal 34 Peraturan Pemerintah Nomor 35 Tahun 2004 tentang Kegiatan Usaha Hulu Minyak dan Gas Bumi yang menyebutkan sejak disetujuinya rencana pengembangan lapangan yang pertama kali akan diproduksi dari suatu wilayah kerja, kontraktor wajib menawarkan participating interest $10 \%$ kepada BUMD. ${ }^{21}$

Kesempatan yang diberikan kepada daerah untuk ikut mengelola sumber daya alam berupa minyak bumi tidak hanya terbatas pada hal tersebut. Hal ini diatur dalam Peraturan Menteri ESDM Nomor 1 Tahun 2008 tentang Pedoman Pertambangan Minyak Bumi pada Sumur Tua yang menyatakan bahwa pengusahaan dan pemroduksian minyak bumi dilaksanakan KUD atau BUMD berdasarkan perjanjian memproduksi minyak bumi dengan Kontraktor. ${ }^{22}$ BUMD yang dimaksud di sini adalah badan usaha tingkat Provinsi/Kabupaten/Kota yang didirikan dan seluruh sahamnya dimiliki oleh Pemerintah Provinsi/Kabupaten/Kota serta wilayah usahanya atau administrasinya mencakup lokasi sumur tua. ${ }^{23}$ KUD yang dimaksud adalah koperasi tingkat kecamatan yang wilayah usahanya mencakup lokasi sumur tua. ${ }^{24}$ Dengan adanya pengusahaan pertambangan minyak bumi pada sumur tua oleh KUD atau BUMD berarti pemerintah memfasilitasi pemenuhan hak daerah untuk turut melakukan pemanfaatan atas sumber daya minyak dan gas bumi yang terletak di wilayah administrasinya.

Untuk dapat bekerja sama memproduksi minyak bumi, KUD atau BUMD mengajukan permohonan kepada Kontraktor dengan tembusan kepada Menteri cq. Direktur Jenderal dan Badan Pelaksana dengan melampirkan dokumen administratif dan teknis. ${ }^{25}$ Permohonan yang dimaksud didasarkan atas rekomendasi dari Pemerintah Kabupaten/ Kota dan disetujui oleh Pemerintah Propinsi. ${ }^{26}$ Dalam hal permohonan pengusahaan minyak bumi pada sumur tua sudah disetujui maka Kontraktor dan KUD atau BUMD wajib menindaklanjuti persetujuan tersebut dengan perjanjian memproduksi minyak bumi. ${ }^{27}$ Pengusahaan pertambangan minyak bumi pada sumur tua dilaksanakan berdasarkan perjanjian tersebut. Untuk selanjutnya, KUD atau BUMD wajib menyerahkan seluruh produksi minyak bumi dari hasil pelaksanaan memproduksi minyak bumi kepada Kontraktor, dengan mutu dan spesifikasi yang telah disepakati dalam perjanjian tersebut. ${ }^{28}$ Kontraktor wajib memberikan imbalan jasa kepada KUD atau BUMD atas seluruh hasil pelaksanaan memproduksi minyak bumi. ${ }^{29}$

Untuk melaksanakan pemroduksian minyak bumi pada sumur tua, BUMD atau KUD harus memenuhi hal-hal yang dipersyaratkan dalam 
dokumen teknis dalam pengajuan permohonan pengusahaan minyak bumi pada sumur tua, yaitu: (1) Rencana program keselamatan dan kesehatan kerja serta pengelolaan lingkungan hidup termasuk usulan penanggung jawab pelaksanaan; (2) Teknologi yang digunakan memproduksikan minyak bumi; dan (3) Kemampuan keuangan. ${ }^{30}$ Namun kenyataannya, KUD atau BUMD yang telah memperoleh persetujuan sekalipun, kerap kali mengalami kesulitan dalam menyediakan biaya, teknologi, dan tenaga kerja demi mempertahankan keberlangsungan pengusahaan sumur tua. Untuk itu, KUD atau BUMD menjalin kerja sama dengan mitra kerja. ${ }^{31}$

Kerja sama antara KUD atau BUMD dengan mitra dapat dijelaskan sebagai berikut: ${ }^{32}$ kerjasama dengan mitra dimaksudkan untuk menjadi sumber pendukung modal, tenaga kerja, dan teknologi. Hal ini memberi jaminan bagi KUD atau BUMD untuk terus mengusahakan sumur tua. Namun, di lain sisi, hal tersebut menimbulkan ketergantungan BUMD terhadap mitra kerjanya dan bersifat kontra produktif terhadap upaya peningkatan daya saing daerah dalam hal pengelolaan sumber daya alam secara mandiri dan berkelanjutan. Kerja sama dengan mitra dilaksanakan berdasarkan perjanjian kerjasama jasa penambangan minyak bumi pada sumur tua. Perjanjian antara BUMD atau KUD dengan mitra kerja meliputi pengadaan peralatan, transportasi, tenaga kerja, modal kerja, dan kegiatan operasional untuk menambang minyak di beberapa sumur tua yang telah disepakati dalam perjanjian pemroduksian dengan KKKS.

Dalam perjanjian kerja sama tersebut, mitra kerja akan mendapatkan hak untuk melaksanakan kegiatan penambangan pada sumur-sumur yang telah disepakati. Untuk hasil produksi yang didapat oleh mitra kerja harus diserahkan seluruhnya kepada KKKS atas nama BUMD atau KUD. Biaya yang timbul dari penyerahan tersebut menjadi tanggung jawab dari mitra kerja. Hasil produksi yang berupa seluruh volume minyak mentah yang dihasilkan oleh mitra kerja setelah diserahkan kepada KKKS akan menghasilkan pendapatan usaha yang dibagi antara BUMD atau KUD dengan mitra kerja sesuai kesepakatan.

Adanya kerja sama yang dilakukan antara KUD atau BUMD dengan mitra kerja tidak diatur dalam Permen ESDM Nomor 1 Tahun 2008. Disebutkan bahwa pengusahaan dan pemroduksian minyak bumi dilaksanakan KUD atau BUMD berdasarkan perjanjian memproduksi minyak bumi dengan Kontraktor. ${ }^{33}$ Dengan demikian, peraturan tersebut merupakan norma terbuka yang memungkinkan pihak lain bekerja sama dengan BUMD atau KUD. Namun, pelaksanaan kerja sama dengan mitra ini bukan hanya menyebabkan BUMD atau KUD bergantung terhadap mitra kerja. Tetapi juga, BUMD atau KUD tersebut hanya sekedar membagi sumur-sumur tua yang didapat, untuk diusahakan oleh mitra kerja atau investor. Hal ini jelas bertentangan dengan tujuan pemberdayaan masyarakat daerah yang

\footnotetext{
Ibid, Pasal 3 ayat (4).

Ananda Prima Yurista, Pelaksanaan Peraturan Pengelolaan Pertambangan Minyak dan Bumi pada Sumur Tua Studi di Kabupaten Blora, (Yogyakarta: Fakultas Hukum, Universitas Gadjah Mada, 2012), hlm. 138.

32 Ibid., hlm. 138-142.

33 Pasal 2 ayat (3) Peraturan Menteri Energi dan Sumber Daya Mineral Nomor 1 Tahun 2008 tentang Pedoman Pengusahaan Pertambangan Minyak Bumi pada Sumur Tua.
} 
termaktub dalam konsideran Permen ESDM Nomor 1 Tahun 2008.

Selain itu, perjanjian kerjasama jasa penambangan minyak bumi pada sumur tua antara BUMD atau KUD justru bersifat kontraproduktif dengan harapan bahwa KUD atau BUMD dapat mengusahakan sumur tua secara aktif, karena dari aspek modal, tenaga kerja, teknologi, hingga transportasi dapat diperjanjikan untuk dilaksanakan oleh mitra kerja. Dengan demikian, adanya perjanjian kerjasama antara BUMD atau KUD tidak akan memberikan kebermanfaatan bagi terwujudnya peningkatan kemampuan daerah dalam mengelola sumber daya alam di wilayahnya secara mandiri dan profesional.

Selanjutnya, perjanjian kerjasama jasa penambangan ini juga berdampak kepada semakin sedikitnya pendapatan yang diperoleh KUD atau BUMD karena imbalan jasa yang didapat dari KKKS harus dibagi kembali dengan mitra kerjanya. Hal ini menyebabkan harapan pengusahaan sumur tua dapat berkontribusi kepada Pendapatan Asli Daerah (PAD) semakin jauh dari kenyataan. Di sisi lain, tujuan pemberdayaan masyarakat daerah pun tidak akan dapat terlaksana dengan baik kecuali hanya sebatas mempekerjakan masyarakat sebagai unskilled worker dengan tingkat kesejahteraan yang rendah.

\section{Politik Pengelolaan Pertambangan Minyak Bumi pada Sumur Tua dalam Rangka Mewujudkan Ketahanan Energi Nasional}

Ketahanan energi menurut Daniel Yergin didefinisikan menurut kedudukan dan kepentingan suatu negara, yaitu ketahanan energi negara pengekspor dan pengimpor energi. Untuk Negara pengekspor energi, ketahanan energi dapat diartikan sebagai bagaimana cara mengamankan pasokan energi mereka untuk menjamin pendapatan finansial sehingga keberlangsungan negara dapat terjamin. Untuknegara pengimpor, Daniel Yergin mengklasifikasikan negara pengimpor menjadi 2 (dua) kelompok, yaitu negara maju dan negara berkembang. Untuk negara maju ketahanan energi dapat terjamin melalui diversifikasi energi, trading dan investasi di wilayah penghasil energi. Sementara untuk negara berkembang ketahanan energi didefinisikan sebagai bagaimana cara mencari penyelesaian untuk menyikapi perubahan energi yang dapat berdampak pada perekonomian negara. ${ }^{34}$

Dalam hal ini, Indonesia merupakan negara pengimpor sekaligus pengekspor minyak bumi. Hal tersebut dibuktikan dengan pernyataan yang dikemukakan oleh Deputi Pengendalian Operasi Badan Pelaksana Kegiatan Hulu Minyak dan Gas Bumi (BP Migas) Gde Pradyana, bahwa Indonesia kita ekspor minyak mentah mencapai 400.000 bph (barel per hari), tapi di sisi lain Indonesia juga mengimpor minyak mencapai 500.000 bph. $^{35}$ Terlepas, apakah Indonesia merupakan negara pengekspor ataupun 
pengimpor, Indonesia berkepentingan untuk mengamankan pasokan energi, demi menjamin pendapatan finansial, serta demi menyikapi perubahan energi yang dapat berdampak pada perekonomian Negara. Perubahan energi yang berdampak pada perekonomian Negara yang dimaksudadalah adanya peningkatan kebutuhan minyak bumi dalam negeri, yang berusaha diatasi dengan melaksanakan impor. Padahal harga minyak bumi di dunia internasional terus menanjak. ${ }^{36} \mathrm{Hal}$ tersebut tentunya memberikan pengaruh signifikan bagi perekonomian Negara sehingga mengamankan pasokan minyak bumi pun sangat penting untuk mengurangi impor yang berpotensi menggerogoti kas Negara.

Pengusahaan minyak bumi pada sumur tua sejak semula memang diperuntukkan demi meningkatkan produksi minyak bumi. Dalam konsideran menimbang Peraturan Menteri Energi dan Sumber Daya Mineral Nomor 1 Tahun 2008 disebutkan secara tegas bahwa tujuan pengusahaan pertambangan minyak bumi yaitu dalam rangka mengoptimalkan produksi pertambangan minyak bumi pada sumur tua. ${ }^{37}$ Kesempatan untuk melaksanakan pengusahaan sumur tua diberikan kepada BUMD dan KUD. ${ }^{38}$ Mengacu pada dasar hukum yang lebih tinggi, BUMD dan Koperasi juga bisa menjadi pelaksana dalam pengelolaan Minyak bumi. ${ }^{39} \mathrm{Hal}$ ini sangat relevan, sebab obyeknya sumur tua terletak dalam wilayah kerja yang ada di daerah, Akan lebih memberdayakan kekuatan lokal dan sesuai dengan semangat desentralisasi, jika daerah, dalam hal ini BUMD dan KUD dapat turut serta dalam pelaksanaan industri migas, sehingga tujuan dari pengelolaan untuk memajukan kemakmuran dan kesejahteraan rakyat dapat terpenuhi.

\section{Quo Vadis Politik Hukum Pertam- bangan Minyak Bumi pada Sumur Tua}

Melihat penjelasan di atas terlihat bahwa pengelolaan pertambangan minyak bumi pada sumur tua bukanlah pengusahaan yang tanpa hambatan. Pertambangan minyak bumi pada sumur tua yang diharapkan mampu menjadi jalan alternatif dalam memenuhi kebutuhan produksi minyak bumi nasional, dihadapkan pada berbagai permasalahan, baik dalam desain norma pengaturan maupun dalam praktik penerapan di lapangan.

Pertama, dalam konteks desain norma pengaturan. Apabila ditelaah lebih lanjut sejatinya peluang pengusahaan minyak bumi pada sumur tua yang diserahkan kepada daerah tidak serta merta membuka pintu keterlibatan daerah melalui BUMD untuk dapat berpartisipasi dalam pengusahaan minyak bumi pada sumur tua. Klausula definisi BUMD dalam Peraturan Menteri ESDM Nomor 1 Tahun 2008 tentang Pedoman Pengusahaan Pertambangan Minyak Bumi pada Sumur Tua memberikan pembatasan yang relatif menyulitkan Pemerintahan Daerah untuk dapat turut serta dalam kegiatan pertambangan minyak bumi. Dalam Pasal 1 angka 4 disebutkan bahwa "Badan Usaha Milik Daerah, selanjutnya disingkat BUMD adalah badan usaha tingkat Propinsi/Kabupaten/Kota

\footnotetext{
$36 \quad$ Ibid.

37 Konsideran menimbang huruf (a) Peraturan Menteri Nomor 1 Tahun 2008 tentang Pedoman Pengusahaan Minyak Bumi pada Sumur Tua.

8 Ibid, Pasal 2 ayat (2).

39 Pasal 9 ayat (1) huruf (c) dan (d) Undang-Undang Nomor 22 Tahun 2001 tentang Minyak dan Gas Bumi (Lembaran Negara Republik Indonesia Tahun 2001 Nomor 136).
} 
yang didirikan dan seluruh sahamnya dimiliki oleh Pemerintah Daerah Propinsi, Kabupaten, dan/atau Kota serta wilayah usahanya atau administratifnya mencakup lokasi Sumur Tua". ${ }^{40}$ Frasa yang menyebutkan "yang didirikan dan seluruh sahamnya dimiliki oleh Pemerintah Daerah" merupakan sebuah pembatasan di tengah keterbatasan alokasi dana daerah yang dipergunakan untuk penyelenggaraan urusan pemerintahan yang lain. Pertambangan sebagai industri yang membutuhkan modal yang besar, tentu semakin memberatkan pemerintah daerah apabila BUMD diharuskan didirikan dan seluruh sahamnya dimiliki oleh pemerintah daerah. Pemerintahan daerah yang sejatinya dibebani urusan pemerintahan yang dijalankan menurut asas otonomi dan tugas pembantuan, ${ }^{41}$ tentu menjadi semakin sulit ketika BUMD yang harapannya dapat memberikan tambahan pendapatan daerah melalui pengusahaan pertambangan minyak bumi, justru disyaratkan harus dimiliki secara penuh oleh pemerintah daerah.

Norma tersebut selain memberatkan dan terkesan setengah hati dalam memberikan kesempatan kepada pemerintah daerah, merupakan norma yang contradictio in propositum dengan tujuan awal pengusahaan pertambangan minyak bumi pada sumur tua. Dalamkonsideranmenimbanghurufadisebutkan "bahwa dalam rangka mengoptimalkan produksi Minyak Bumi dalam suatu wilayah kerja yang di dalamnya terdapat Sumur Tua dan untuk meningkatkan kesejahteraan masyarakat di sekitar lokasi Sumur Tua, perlu dilakukan pengusahaan pertambangan Minyak Bumi pada sumur tua dengan mengikutsertakan partisipasi masyarakat sekitarnya", 42 tentu bertentangan dengan pembatasan BUMD yang dapat melakukan pengusahaan pertambangan minyak bumi pada sumur tua. Terlebih pembatasan nomenklatur BUMD juga bertentangan dengan semangat pengaturan yang lebih tinggi. Dalam Pasal 34 Peraturan Pemerintah Nomor 35 Tahun 2004 tentang Kegiatan Usaha Hulu Minyak dan Gas Bumi disebutkan bahwa "Sejak disetujuinya rencana pengembangan lapangan yang pertama kali akan diproduksikan dari suatu Wilayah Kerja, Kontraktor wajib menawarkan participating interest 10\% (sepuluh per seratus) kepada Badan Usaha Milik Daerah". ${ }^{43}$ Dalam konteks ini bahkan BUMD diberikan tempat yang dikhususkan oleh PP a quo karena kontraktor wajib menawarkan participating interest pada BUMD.

Dengan demikian, dari perspektif politik hukum pengaturan sejatinya Peraturan Menteri ESDM Nomor 1 Tahun 2008 telah bertentangan dengan Peraturan Pemerintah Nomor 35 Tahun 2004. Bahkan pengaturan dalam Permen ESDM a quo memberikan pengaturan yang berlebihan dalam memberikan syarat penyertaan modal yang notabene bertentangan dengan UU Nomor 17 Tahun 2003 tentang Keuangan Negara, ${ }^{44}$ UU Nomor 1 Tahun 2004 tentang Perbendaharaan

40 Pasal 1 angka 4 Peraturan Menteri Energi dan Sumber Daya Mineral Nomor 1 Tahun 2008 tentang Pedoman Pengusahaan Pertambangan Minyak Bumi pada Sumur Tua.

$41 \quad$ Pasal 18 ayat (2) Undang-Undang Dasar Negara Republik Indonesia Tahun 1945.

42 Konsideran Menimbang huruf b Peraturan Menteri Energi dan Sumber Daya Mineral Nomor 1 Tahun 2008 tentang Pedoman Pengusahaan Pertambangan Minyak Bumi pada Sumur Tua.

43 Pasal 34 Peraturan Pemerintah Nomor 35 Tahun 2004 tentang Kegiatan Usaha Hulu Minyak dan Gas Bumi (Lembaran Negara Republik Indonesia Tahun 2004 Nomor 123 Tambahan Lembaran Negara Republik Indonesia Nomor 4435).

44 Pasal 24 Undang-Undang Nomor 17 Tahun 2003 tentang Keuangan Negara (Lembaran Negara Republik Indonesia Tahun 2003 Nomor 47, Tambahan Lembaran Negara Nomor 4286). 
Negara, ${ }^{45}$ dan Peraturan Pemerintah Nomor 1 Tahun 2008 tentang Investasi Pemerintah. ${ }^{46}$ Pun Permen ESDM a quo telah membuka kesempatan kepada BUMD, tetapi Permen ESMD lebih membatasi sesuatu yang sejatinya tidak dibatasi oleh pengaturan yang lebih tinggi.

Tentu menjadi tidak pantas ketika participating interest yang ditawarkan kepada BUMD dan diterima oleh BUMD menurut Peraturan Pemerintah Nomor 35 Tahun 2004, namun menjadi batal secara formil semata karena BUMD tidak dimiliki sepenuhnya oleh daerah menurut Permen ESDM Nomor 1 Tahun 2008. Adanya inkonsistensi pengaturan tersebut menunjukkan bahwa ego sektoral dalam pengaturan terlihat sangat kental. Bahwa pertambangan bukan semata menjadi domain kewenangan Kementerian ESDM, tetapi juga bersinggungan secara langsung dengan pemerintahan daerah sebagai locus keberadaan situs pertambangan.

Kedua, Peraturan Menteri ESDM Nomor 1 Tahun 2008 mempunyai beberapa kelemahan yang mendasar yakni, perihal desain sumur tua yang terdapat dalam wilayah kerja pertambangan. Dari desain peraturan perundang-undangan saat ini seolah-olah BUMD dan KUD hanya kepanjangan tangan kontraktor semata dan tidak dapat melaksanakan pengelolaan minyak secara mandiri. BUMD dan KUD hanya sub kontraktor sehingga BUMD dan KUD hanya berhak mendapatkan imbalan.

Hal ini disebabkan karena sumur tua yang dikelola oleh BUMD atau KUD berada dalam wilayah kerja Kontraktor. Padahal sumur tua tersebut terletak pada lapangan yang tidak diusahakan di suatu wilayah kerja yang terikat Kontrak Kerja Sama dan tidak diusahakan lagi oleh Kontraktor. ${ }^{47}$ Seharusnya desain pengelolaan ini dapat disesuaikan dengan Pasal 16 Undang-Undang Nomor 22 Tahun 2001 yang menyebutkan “Badan Usaha atau Bentuk Usaha Tetap wajib mengembalikan sebagian wilayah kerjanya secara bertahap atau seluruhnya kepada Menteri" sehingga sumur tua dapat kembali dalam penguasaan Pemerintah. Dengan demikian, ketika BUMD dan KUD mengajukan permohonan pengelolaan sumur tua, BUMD dan KUD mendapatkan peluang untuk mengelola minyak secara mandiri, bukan lagi sebagai sub kontraktor seperti saat ini.

Ketiga, aspek inkonsistensi politik hukum pengaturan pengelolaan pertambangan minyak bumi pada sumur tua menjadi lebih rumit, terlebih dikarenakan pada aspek praksis pengusahaan minyak bumi pada sumur tua juga dibenturkan pada permasalahanpermasalahan sebagai berikut: ${ }^{48}$ Permasalahan Pertama, ketersediaan modal. BUMD atau KUD mengalami hambatan dalam aspek permodalan. Pengusahaan pertambangan minyak pada sumur tua merupakan usaha yang membutuhkan modal yang besar, sehingga ketika permohonan pengusahaan minyak bumi pada sumur tua telah disetujui, maka mereka mengawali kegiatan pengusahaan dengan modal yang terbatas, sehingga akhirnya BUMD atau KUD berusaha untuk mendapatkan mitra kerja

$45 \quad$ Pasal 1 Undang-Undang Nomor 1 Tahun 2004 tentang Perbendaharaan Negara (Lembaran Negara Republik Indonesia Tahun 2004 Nomor 5, Tambahan Lembaran Negara Republik Indonesia Nomor 4355).

46 Pasal 1 Peraturan Pemerintah Nomor 1 Tahun 2008 tentang Investasi Pemerintah (Lembaran Negara Republik Indonesia Tahun 2008 Nomor 14, Tambahan Lembaran Negara Republik Indonesia Nomor 4812).

47 Pasal 1 angka (2) Peraturan Menteri Energi dan Sumber Daya Mineral Nomor 1 Tahun 2008 tentang Pedoman Pengusahaan Pertambangan Minyak Bumi pada Sumur Tua.

48 Ananda Prima Yurista, Op.cit., hlm. 163-168. 
atau investor yang dapat memberikan modal, bantuan teknis, tenaga kerja yang kompeten, membiayai transportasi, pembangunan, infrastruktur, dan gaji tenaga kerja. Ketika modal tidak tersedia, tidak jarang BUMD atau KUD tersebut menghentikan kegiatan pengusahaan hingga mendapatkan mitra kerja atau investor.

Permasalahan Kedua, data sumur tua. Sumur tua merupakan sumur yang telah lama tidak diusahakan sejak tahun 1970. Hal tersebut menyebabkan sulitnya menemukan data untuk memperkirakan seberapa banyak kuantitas minyak bumi yang masih dapat diambil dari satu buah sumur tua, sehingga sukar untuk diketahui mana sumur yang masih produktif dan mana sumur yang sudah tidak produktif. Untuk mendapatkan data tentang sumur tua, BUMD atau KUD menggunakan banyak cara, mulai dari melakukan riset yang membutuhkan banyak biaya, pendekatan sosial untuk mendapat informasi dari masyarakat sekitar, mencari data yang masih dipegang oleh orang per orang, baik dosen perguruan tinggi maupun dari orang-orang yang merupakan mantan pekerja perusahaan minyak bumi di masa lalu. Dengan cara-cara tersebut akhirnya didapatkan beberapa informasi dan data mengenai beberapa sumur tua yang akan diusahakan.

Permasalahan Ketiga, hambatan teknis di lapangan. Pengusahaan minyak bumi pada sumur tua dilaksanakan dengan dua jenis metode, yaitu dengan cara ditimba atau dipompa dengan mesin modern. Dalam hal pelaksanaan pengusahaan dengan cara manual, yaitu ditimba, kendala yang dihadapi adalah dengan banyak tenaga kerja yang harus dikerahkan untuk menimba minyak yang ada di sumur tua tersebut. Selain itu, hasil yang didapat dari cara manual tersebut tidak terlalu banyak. Sedangkan dengan cara dipompa yang menjadi kendala adalah alat pompa tersebut sangat mahal harganya dan untuk mendapatkannya membutuhkan waktu yang lama karena alat pompa tersebut hanya diproduksi di luar negeri. Selain itu, BUMD atau KUD mengalami kesulitan pula dalam mendapatkan tenaga kerja yang kompeten karena kepemilikan modal yang terbatas. Tenaga kerja yang diharapkan hanya berasal dari masyarakat sekitarlokasi sumur tua, yang rata-rata hanya memahami pengusahaan pertambangan minyak bumi pada sumur tua dengan metode manual dan teknologi yang sederhana.

Permasalahan Keempat, aspek lahan lokasi sumur tua. Letak sumur tua terdapat di wilayah kerja KKKS. Sumur tua tidak diusahakan dalam waktu yang lama. Beberapa dari lokasi sumur tua telah menjadi pemukiman warga, sehingga beberapa sumur tua tersebut ada di lahan warga. Oleh karena itu, BUMD atau KUD tetap harus membayar sejumlah ganti rugi untuk pembebasan lahan lokasi sumur tua tersebut. Selain itu, ada beberapa lokasi sumur tua yang terletak di dalam kawasan Perhutani. Peta wilayah tidak dapat ditemukan, sehingga BUMD atau KUD harus mencari peta tersebut untuk membuktikan bahwa wilayah tersebut masuk dalam wilayah kerja KKKS. Seringkali KKKS sendiri tidak mempunyai peta tersebut, sedangkan Perhutani pun memiliki peta yang berbeda, yang merupakan peta versi Perhutani. Oleh karena hambatan tersebut BUMD atau KUD juga kerap berhenti melaksanakan pengusahaan pertambangan minyak bumi pada sumur tua sampai permasalahan lahan tersebut terselesaikan.

Permasalahan Kelima, pengawasan. Pengawasan terhadap pelaksanaan pengusahaan minyak bumi pada sumur tua dilaksanakan oleh Dirjen Migas, Badan 
Pelaksana, dan Pemerintah Daerah Kabupaten/ Kota. Dalam jangka waktu yang tidak ditentukan secara jelas, Dirjen Migas dapat melaksanakan kegiatan inspeksi langsung ke lapangan. Badan Pelaksana mengawasi langsung ke lapangan, jika memang ada indikasi pelanggaran atas perjanjian, sedangkan Pemerintah Daerah Kabupaten/Kota menunggu laporan tertulis dari BUMD atau KUD yang bersangkutan. Dan dalam kenyataannya, pengawasan lebih banyak dilaksanakan oleh KKKS. Padahal, ketika permohonan pengusahaan minyak bumi pada sumur tua telah disetujui, yang kemudian ditindaklanjuti dengan pembuatan perjanjian antara KKKS dan BUMD atau KUD, pendekatan yang terjadi antara KKKS dan BUMD atau KUD merupakan pendekatan $B$ to $B$ atau Bisnis to Bisnis. Prinsip $B$ to $B$ tersebut juga menjadi kendala tersendiri untuk jalannya pengawasan yang lebih intensif oleh pihak-pihak yang bertanggung jawab.

Berdasarkan pemaparan di atas, diperlukan pembenahan yang holistik, baik dari aspek norma pengaturan, maupun dari aspek praksis pelaksanaan pengusahaan minyak bumi pada sumur tua. Pembenahan holistik tersebut di antaranya adalah dengan merubah frasa yang mempersyaratkan kepemilikan saham BUMD sepenuhnya pada Pemerintah Daerah, yang terdapat dalam Pasal 1 angka 4 Permen ESDM Nomor 1 Tahun 2008. ${ }^{49}$ Dengan diubahnya norma dalam pasal a quo akan membuka peluang bagi Pemerintah Daerah untuk mendirikan BUMD dengan mengajak mitra lain untuk melakukan penyertaan modal dalam saham BUMD tersebut. Terlebih Pasal 1 angka 4 ini bertentangan dengan Pasal 24
Undang-Undang Nomor 17 Tahun 2003, Pasal 41 Undang-Undang Nomor 1 Tahun 2004 dan Pasal 1 Peraturan Pemerintah Nomor 1 Tahun 2008, yang sama sekali tidak mempersyaratkan adanya kepemilikan saham seluruhnya dalam penyertaan modal yang dilakukan Pemerintah Daerah pada suatu perusahaan daerah. Dengan dibukanya peluang tersebut maka, permasalahan ketersediaan modal, hambatan teknis di lapangan, bahkan aspek lahan lokasi pertambangan minyak bumi dapat teratasi.

Selain itu, untuk memberikan kesempatan bagi BUMD dan KUD untuk mengelola pertambangan minyak bumi pada sumur tua, maka pemerintah harus melaksanakan implementasi norma dalam Pasal 16 dan Pasal 17 Undang-Undang Nomor 22 Tahun 2001 mengenai pengembalian wilayah kerja. Bahkan jika pengembalian wilayah kerja menjadi tidak relevan dalam optimalisasi peran daerah dalam pengelolaan minyak bumi pada sumur tua, maka perubahan norma pengembalian wilayah kerja menjadi pengembalian sumur tua menjadi suatu yang niscaya. Hal ini semata-mata sebagai sebuah upaya agar pengelolaan minyak bumi pada sumur tua dapat dilakukan BUMD dan KUD secara mandiri, sehingga pengelolaan minyak bumi pada sumur tua dapat secara optimal turut serta meningkatkan kesejahteraan masyarakat daerah.

\section{Penutup}

Pengelolaan pertambangan minyak bumi pada sumur tua merupakan salah satu strategi dalam peningkatan produksi minyak bumi nasional. Namun, dalam kenyataannya

49 Pasal 1 Peraturan Menteri Energi dan Sumber Daya Mineral Nomor 1 Tahun 2008 tentang Pedoman Pengusahaan Pertambangan Minyak Bumi pada Sumur Tua. 
pemanfaatan kembali atau re-opening sumur tua ini masih dipandang sebelah mata. Adanya peluang yang diberikan kepada BUMD atau KUD untuk ikut mengusahakan sumur tua menjadi sebuah harapan baru untuk dapat mengoptimalisasi produksi minyak bumi pada sumur tua sebagai salah satu strategi menuju ketahanan energi di Indonesia. Namun perwujudan strategi tersebut bukan tanpa hambatan. Hambatan-hambatan tersebut diuraikan sebagai berikut: Pertama, dalam konteks desain norma pengaturan. Apabila ditelaah lebih lanjut sejatinya peluang pengusahaan minyak bumi pada sumur tua yang diserahkan kepada daerah tidak serta merta membuka pintu keterlibatan daerah melalui BUMD untuk dapat berpartisipasi dalam pengusahaan minyak bumi pada sumur tua. Kedua, Peraturan Menteri ESDM Nomor 1 Tahun 2008 mempunyai beberapa kelemahan yang mendasar yakni, perihal desain sumur tua yang terdapat dalam wilayah kerja pertambangan. Ketiga, aspek inkonsistensi politik hukum pengaturan pengelolaan pertambangan minyak bumi pada sumur tua menjadi lebih rumit, terlebih dikarenakan pada aspek praksis pengusahaan minyak bumi pada sumur tua juga dibenturkan pada permasalahan-permasalahan sebagai berikut: (1) ketersediaan modal; (2) data sumur tua. Sumur tua merupakan sumur yang telah lama tidak diusahakan sejak tahun 1970; (3) hambatan teknis di lapangan; (4) aspek lahan lokasi sumur tua; dan (5) pengawasan. Berdasarkan pemaparan di atas, diperlukan pembenahan yang holistik, baik dari aspek norma pengaturan, maupun dari aspek praksis pelaksanaan pengusahaan minyak bumi pada sumur tua. Pembenahan holistik tersebut di antaranya adalah dengan merubah frasa yang mempersyaratkan kepemilikan saham BUMD sepenuhnya pada Pemerintah Daerah, yang terdapat dalam Pasal 1 angka 4 Permen ESDM Nomor 1 Tahun 2008 serta dengan merubah norma dalam Pasal 16 dan Pasal 17 UndangUndang Nomor 22 Tahun 2001 mengenai pengembalian wilayah kerja.

\section{DAFTAR PUSTAKA}

\section{Buku}

Kotarumalos, Nur Aisyah, Menuju Ketahanan Energi Indonesia: Belajar dari Negara Lain, (Jakarta: Cakra Studi Global dan Strategis, 2009).

Manan, B., Beberapa Catatan Atas Rancangan Undang-Undang tentang Minyak dan Gas Bumi, (Bandung: Fakultas Hukum Universitas Padjadjaran, 1999).

Sinaga, N.F., Participating Interest dalam Kegiatan Usaha Hulu Minyak dan Gas Bumi Ditinjau dari Otonomi Daerah (Keikutsertaan BUMD dalam Participating Interest Blok Cepu), (Jakarta: Fakultas Hukum Universitas Indonesia, 2009).

Yurista, Ananda Prima, Pelaksanaan Peraturan Pengelolaan Pertambangan Minyak dan Bumi pada Sumur Tua Studi di Kabupaten Blora, (Yogyakarta: Fakultas Hukum, Universitas Gadjah Mada, 2012).

\section{Makalah/Artikel/Prosiding/Hasil Penelitian}

Djumena, Erlangga, "Indonesia Defisit Minyak Bumi 608.000 Barrel Per hari," (Kompas, 24 Maret 2014).

S., Asikin, "Pengembangan Potensi Sumber Daya Mineral Menyongsong Otonomi Daerah," (Makalah Seminar dan MUNAS I Ikatan Alumni Tambang Jurusan Teknik Pertambangan UPN Veteran Yogyakarta, Yogyakarta, 23 Juni 2000).

\section{Internet}

Deil, Siska Amelie F., "Kisah Indonesia yang Tercoret dari Daftar Negara Kaya Minyak", http://m. liputan6.com/bisnis/read/786193/kisahIndonesia-yang-tercoret-dari-daftar-negarakaya-minyak? $p=2$ (diakses 5 Oktober 2015).

Dhany, Rista Rama, "Ini Alasan Indonesia Masih Impor 500.000 barel per/hari", http://finance. detik.com/read/2012/08/03/122329/1982326 


\section{RECHTSRISINDING}

Media Pembinaan Hukum Nasional

/1034/ini-alasan-Indonesia-masih-impor-bbm500000-barel-hari (diakses 15 Juni 2015).

Indonesia Investment, "Minyak \& Gas Indonesia: Produksi Minyak Mentah Meningkat di 2015?", http://www.Indonesia-investments.com/id/ berita/kolom-berita/minyak-gas-Indonesiaproduksi-minyak-mentah-meningkat-di-2015/ item5385 (diakses 15 Juni 2015).

Jumina dan Karna Wijaya, "Ketahanan Energi dan Kebijakan BBM di Indonesia", http://pse.ugm. ac.id/? $p=413$ (diakses 15 Juni 2015).

Kementerian Energi dan Sumber Daya Mineral, "13 Ribu Sumur Minyak Bumi Tua Ditawarkan Kepada KUD dan BUMD", http://esdm.go.id/ berita/40-migas/1636-13-ribu-sumur-minyakbumi-tua-ditawarkan-kepada-kud-dan-bumd. html (diakses 15 Juni 2015).

\section{Peraturan}

Undang-Undang Dasar Negara Republik Indonesia Tahun 1945.

Undang-Undang Nomor 23 Tahun 2014 tentang Pemerintahan Daerah (Lembaran Negara Republik Indonesia Tahun 2014 Nomor 244).

Undang-Undang Nomor 22 Tahun 2001 tentang Minyak dan Gas Bumi (Lembaran Negara
Volume 4, Nomor 2, Agustus 2015

Republik Indonesia Tahun 2001 Nomor 136, Tambahan Lembaran Negara Republik Indonesia Nomor 4152).

Undang-Undang Nomor 1 Tahun 2004 tentang Perbendaharaan Negara (Lembaran Negara Republik Indonesia Tahun 2004 Nomor 5, Tambahan Lembaran Negara Republik Indonesia Nomor 4355).

Undang-Undang Nomor 17 Tahun 2003 tentang Keuangan Negara (Lembaran Negara Republik Indonesia Tahun 2003 Nomor 47, Tambahan Lembaran Negara Nomor 4286).

Peraturan Pemerintah Nomor 1 Tahun 2008 tentang Investasi Pemerintah (Lembaran Negara Republik Indonesia Tahun 2008 Nomor 14, Tambahan Lembaran Negara Republik Indonesia Nomor 4812).

Peraturan Pemerintah Nomor 35 Tahun 2004 tentang Kegiatan Usaha Hulu Minyak dan Gas Bumi (Lembaran Negara Republik Indonesia Tahun 2001 Nomor 123, Tambahan Lembaran Negara Republik Indonesia Nomor 4435).

Peraturan Menteri Energi dan Sumber Daya Mineral Nomor 1 Tahun 2008 tentang Pedoman Pengusahaan Pertambangan Minyak Bumi pada Sumur Tua. 